\title{
DIE STEM VAN DIE KERK IN DIE WERELD
}

\author{
PROF. DR. F. J. VAN ZYL
}

\section{INLEIDING}

Dit is inderdaad geen diepsinnige uitspraak nie, en daar word beslis geen buitengewone beroep op teologiese insig of gespanne aandag gemaak as gekonstateer word dat die drie trefwoorde in die tema van hierdie voordrag bestaan uit die klein bekende woordjies: stem, kerk en wêreld. Elkeen wat die kerk en die wêreld ken sal ongetwyfeld saamstem dat ons beslis nie met $n^{\prime}$ probleemlose saak te doen het nie, nog wat die afsonderlike trefwoorde betref, nóg wat die samehang betref waarin hulle hier gebruik word. Veel eer is die teendeel waar. Ons betree met hierdie drie bekende woorde 'n probleemveld wat so intens en omvattend is dat dit ' $n$ mens onwillekeurig laat dink aan die verslae uitspraak van 'n besoeker aan die karoo nadat hy ure oor die eindelose eenselwigheid getuur het: "It is the vastness that kills me." Om uit hierdie ontsaglik wye probleemgebied ' $n$ seleksie te maak wat belangwekkend sal wees, is uiters moeilik en daarom is dit miskien die verstandigste om daarvan af te sien. Miskien sal dit die vrugbaarste wees om die ganse probleemkompleks rondom die tema maar aan die orde te stel en langs die weg van reduksie te probeer deurdring na die essensie. Vanweë die ontsaglikheid van die probleme is dit miskien die beste om hulle in drie lae ter sprake te bring:

(a) ' $n$ bolaag waar dit om die opsigtelike en voor die hand liggende probleme gaan,

(b) ' $n$ tweede laag waar dit om dieperliggende probleme gaan, en

(c) 'n grondlaag waar dit om die wesenlike probleme gaan.

\section{DIE OPSIGTELIKE PROBLEME}

2(i). Die eerste vraag wat na vore kom, is wat onder die stem van die kerk verstaan moet word. Die kerk se stem kan natuurlik op verskillende maniere hoorbaar word, hoofsaaklik in die geartikuleeide, en in die geskrewe woord as neerslag van die gesproke, woord. Sowel in die gesproke as die geskrewe gestalte kan die stem van die kerk opsetlik gerig wees tot die wêreld, in sy missionêre prediking en in sy teologiese geskrifte. Hoewel nie direk tot die wêreld gerig nie, kan die stem van die kerk in die wêreld ook hoorbaar word in sy belydenis, sy gebed en sy lied. Hoewel die belydenis ' $n$ uitsluitlike handeling van die gelowende gemeente is, $k a n$ dit by tye tog ' $n$ belydenis voor die wêreld wees en as sodanig kan dit ook missionêre betekenis hê. Die stem van die kerk in die 
gebed geskied nie in woorde wat tot die wêreld gerig word nie, maar dit is ten hemel gerig ten behoewe van die wêreld. Dit beteken nie dat die wêreld by geleentheid ook verneem, al is dit dan nie in die direkte gebedswoorde nie, wat die strekking en bedoeling van die gebed van die kerk is, yir die mense binne sowel as buite die kerk. Miskien is dit ook maar goed dat die kerk nie alles waarom hy bid by die wêreld laat bekend word nie, want ' $n$ mens wonder wat hy sal dink van wat onlangs in die pers wye publikasie gekry het, dat gelowiges opgeroep is om tydens ' $n$ ontkleedansvertoning vir die danseres te bid, en dat gemeentelede van die kansel opgeroep is om te bid dat ' $n$ dominee sy luukse motor terug mag vind wat gesteel is. Ook in sy lied is die stem van die kerk nie direk gerig tot die wêreld nie, want dis immers 'n lied wat aan God gewy word. Vir die kerk is ook dit geen probleemlose aangeleentheid nie. Nie alleen gaan die vraag oor wat daar gesing moet word nie, maar hier by ons het dit vandag 'n baie brandende vraag geword hoe daar gesing moet word: koralies of modalies. Die stem van die kerk word natuurlik ook in die wêreld gehoor deur die kanselboodskappe en herderlike skrywers wat hy van tyd tot tyd tot sy eie lede rig. Hoewel dit aan die lede binne die kerk gerig word, gaan dit gewoonlik ook nie ongehoord by die wêreld buite die kerk verby nie. Deur middel van die massamedia van ons tyd, word wat aan die kerk seff gerig word, soms ook rugbaar gemaak in die wêreld. Aangesien hierdie media nie deur die kerk beheer word nie, kies hulle natuurlik redelik arbitrêr wat hulle rugbaar wil laat word in die wêreld, en heel dikwels met ' $n$ vooropgestelde doel. Behalwe die min-of-meer offisiële spraak van die kerk in prediking, getuienis, belydenis, gebed, boodskap, ens., word die stem van die kerk in die wêreld ook nog gehoor deur die uitsprake van sy lede in woord en geskrif. Rondom hierdie woorde as stem van die kerk lê daar heelwat vrae, maar hulle kom eintlik beter ter sprake onder ' $n$ volgende hoof waar die klem in die problematiek rondom die stem van die kerk, meer op die woord ,kerk" val.

2(ii). As 'n mens van die stem van die kerk praat. het jy nie met ' $n$ ondubbelsinnige uitspraak te doen nie. Daar is kerk en kerk. Daar is die stem van die Roomse kerk, van die Anglikaanse kerk, van die Protestantse kerk en nog ander. Nie almal laat dieselfde stem hoor in belydenis, in liturgie, in prediking en teologie nie. Selfs nie deur die drie Afrikaanse kerke wat volgens ons opvattings binne die Bybelse begrip van die eenheid van die kerk bymekaar behoort, word dieselfde stem in die wêreld laat hoor nie. Die mees formidabele kerklike stem in die wêreld vandag is waarskynlik die van die Wêreldraad van Kerke. Omdat geen kerk van Christus ' $n$ ander roeping het as om die Woord van God in die wêreld te spreek nie, kan ons hierdie deel van ons tema maar onmiddellik tot die essenșiẹle reduseer: dit gaan nie om die stem van hierdie of daardie kerk 
in die wêreld nie, maar om die stem van ons eie kerk, die Ned. Herv. Kerk van Afrika. Dit beteken nie dat ons stem - soos miskien soms gedink word - die belangrikste in die wêreld is nie, maar dit impliseer alleen dat ons verantwoordelikheid moet aanvaar vir wat ons as kerk in ons klein deeltjie van die groot wêreld sê en behoort te sê. Dit beteken nou ook nie weer dat ons nie moet luister na wat die res van die kerk in die wêreld te sê het nie. Hoewel ons nie altyd met mekaar kan saamstem nie, hoewel ons soms ernstig en radikaal van mekaar verskil en beswaarlik na mekaar kan luister, is dit tog nodig dat kerke nie verder as ten minste hoorbreedte van mekaar verwyder sal wees nie. Dit kan God behaag om ons ook lets te laat leer selfs van die kerke van wie ons miskien die verste verwyder staan. Bowendien is dit niks meer as billik nie dat 'n mens ten minste grondig sal weet wat 'n ander sê, as jy reken dat jyself iets anders en beters moet sê.

Wat ons reeds in die algemeen oor die stem van die kerk gesê het m.b.t. prediking, belydenis, lied, ens., geld m.m. ook van ons eie kerk. Oor die stem van die kerk soos wat dit hoorbaar word in die uitspraak en geskrif van die afsonderlike lede, moet nog een-enander bygevoeg word. Ook hier rys daar allerlei vrae. Is dit die stem van die kerk wat van die kateder af gehoor word? Is dit die stem van die kerk wat 'n mens hoor as Ds. of Prof. so-en-so 'n opinie in die koerant, ' $n$ tydskrif of die radio lug? Is dit die stem van die kerk wat gehoor word as van sy ampsdraers of lede in die wêreldlike hof moet praat? Is dit die stem van die kerk wat ons hoor as Ds. of Prof. so-en-so gevra word deur hierdie of daardie vergadering of organisasie vir 'n toespraak oor hierdie of daardie aktuele saak?

2(iii). Miskien is dit die plek hier om een-en-ander te sê oor wat onder kerklike spreke verstaan moet word. Wanneer is 'n uitspraak 'n kerklike uitspraak? Wat maak die uitspraak van 'n kerk of ' $n$ lid van die kerk anders as die uitspraak van 'n vergadering van een of ander wêreldse organisasie? Om daarop te antwoord, is dit nodig om kortliks te sê wat 'n kerk anders maak as enige ander vergadering ter wêreld. En nou is die bedoeling nie om 'n dogmatiese definisie van die kerk te gee nie. Maar wat ook anders van die grootheid "kerk" gesê mag word, is daar twee persone wat nooit mag ontbreek nie, en dit is God en mens. Sonder enigeen van hierdie twee, is daar geen kerk nie. Dis die enigste gemeenskap in die wêreld waar God en mens in een verband genoem word. God in die kerk is die waarborg van die gesag van die kerk en van die outoriteit van sy uitsprake. In die kerk spreek God alleen, maar deur die mond van mense. As die kerk praat, sê hy wat God sê. Hy sê: so sê die Here. Met ander woorde, die kerk praat alleen uit die openbaring. Alles wat hy sê, is in allerlaaste instansie 'n wyse van skrifuitleg. Omdat dit mense is wat in die kerk spreek, dra alle kerklike uitsprake iets relatiefs, hoofsaaklik geld dit die spreke buite die prediking. 
Kerklike spreke verdien hierdie kwalifikasie nie omdat een van sy hoogste gesagsliggame 'n uitspraak maak nie, maar dis kerklike uitspraak in sover dit Bybels verantwoord is. Kerklike spreke is Bybelse spreke. ${ }^{1}$ ) So gesien kan 'n lid van die kerk in bybelse gehoorsaamheid soms anders as 'n kerklike vergadering praat. Te meer so, omdat ons ook nie glo aan 'n offisiële kerklike teologie nie. In gehoorsaamheid aan die Skrif en binne die grense van die belydenis, moet daar 'n ruime mate van vryheid in die kerklike spreke toegelaat word, maar ons moet in gedagte hou dat die wêreld ook sulke individuele uitsprake var afsonderlike lede en ampsdraers aan 'n kerk koppel, asof dit die heersende opvatting van die kerk is. Des te meer word daardeur 'n besondere verantwoordelikheid op elke afsonderlike spreker in die kerk gelê om met waardigheid na die beste van sy vermoë altyd in gehoorsaamheid aan die Skrif sy stem in die wêreld te laat hoor, of anders maar liewer te swyg.

2(iv). 'n Laaste groep opsigtelike probleme lê rondom die woord "wêreld". Dis nodig om ook hier afgrensings te maak ten opsigte van die verskillende betekenisse wat hierdie woord kan hê. Aanvanklik het die Bybel nie 'n begrip of woord gehad vir wat later via die Septuaginta met die woord "kosmos" aangedui is nie. Genesis praat nie van die skepping van die wêreld nie, maar van die hemel en die aarde. ${ }^{2}$ ) en Ps. 8 praat van ,.alles“ wat God onder die voet van die mens geplaas het. Wêreld kan die heelal met mens, dier, plant en al die natuurlike dinge beteken. Hoofsaaklik word met die woord die mensewêreld bedoel, die wêreld as goeie skepping van God voor die sondeval, maar veral die wêreld as mensheid wat in sonde geval het. Die Bybel praat in hierdie verband van die wêreld as die in die leifde van God oorwonne wêreld. As ons in die verband van ons tema praat van die stem van die kerk in die wêreld, impliseer dit die stem in die wêreld van die mense.

\section{DIE DIEPERLIGGENDE PROBLEME}

3(i). Wanneer ons die dieperliggende probleme rondom die woorde stem, kerk en wêrela nader betrag, wil ons dit in omgekeerde volgorde doen en wat laaste is laat voorgaan. Ons doen dit doelbewus, omdat ' $n$ groot deel van die problematiek betreffende die stem van die kerk, bepaal word deur die problematiek rondom die woord "wêreld". 'n Eerste saak wat aandag verdien, is die kwessie van die verskil tussen kerk en wêreld. Dis duidelik dat albei aan God behoort. Dis God se wêreld en dis God se kerk. Die kerk

1) Dr. J. Koopmans, Onder het Woord, Uitgeversmaatschappy Amsterdam, 1949, p. 205.

2) Uirich Mann, Theologische Religionsphilosophie im Grundrisz, FurcheVerlag Hamburg, 1960, S. 64. 
bestaan ook nie as platoniese idee iewers los van die wêreld nie, maar staan vierkantig in hierdie wêreld geplant. Daar is geen ander kerk as die kerk wat in die wêreld sigbaar word nie. Die kerk bestaan ook nie uit ander mense as die wat in die wêreld gevind word nie. Die mense in die kerk is dieselfde as die mense daarbuite, nie mooier, ook nie beter nie, maar tog anders omdat hulle deur die regverdigende Woord van God anders verklaar word. Binne en buite die kerk vind ons net sondaars, met die verskil dat ons binne die kerk sondaars vind wat weet dat hulle begenadigde sondaars is. Die kerk, sou ons dus kan sê, is deel van die wêreld, dis daardie deel van die wêreld wat vry geword het onder die heerskappy van satan en sonde uit, en weer teruggebring is in die vaderland waar God die hemelse Vader as enigste Heer erken, gedien en gevrees word. Omdat die kerk so 'n deel van die wêreld is, kon Barth ${ }^{3}$ ) sê dat die kerk daardie gemeenskap is aan wie dit genadiglik geskenk is om die wêreld te ken soos hy is, aan wie dit genadiglik geskenk is om hom solidêr met die wêreld te voel, aan wie dit genadiglik geskenk is om te weet wat die werklike nood van die wêreld is, omdat dit geen ander nood is as die een waaruit hy self genadiglik gered is nie. Hy het ook geen ander boodskap vir die wêreld as die bekendmaking van die hulp en genade wat hy self ervaar het tot sy vryheid en vreugde toe hy self nog wêreld was en geen vrede en vreugde geken het nie.

3(ii). Maar hierdie wêreld buite die kerk was deur al die eeue aan veranderinge onderworpe hoewel hy wesenlik dieselfde gebly het: wêreld in sy vervreemding van God. Hierdie wêreld het in ons eeu radikale veranderinge ondergaan. Die kerk het vandag met 'n ander wêreld te doen as die apostel Paulus, omdat iets van die sendingdoel soos wat die apcstel en die oergemeente dit verstaan het, vandag in die wêreld tereg gekom het. Juis die verbreiding van die evangelie in die wêreld het die wêreld verwêreld in die sin dat al drie sakrate, die heilige, demoniese en goddelike van hom afgestroop is. Vandag word gepraat van die gesekulariseerde, ontdemoniseerde, ontdiviniseerde en gehominiseerde wêreld. Sedert Bonhoeffer hoor ons van die mondige mens en wêreld. Daar is in ons eie kringe al baie oor die lig en donker van die gesekulariseerde wêreld gepraat. Miskien moet ons maar aanvaar dat daar ook 'n ligkant aan die sekularisasie erken moet word. Ons $k a n$ tog nie ontken dat die evangelie mens en wêreld vry maak nie. Die evangelie ontgoddelik die wêreld en dit ontwêreld die mens. Die ontgoddeliking beteken dat die Bybel God nooit as deel van die wêreld sien soos dit tipies by die heidendom is nie, maar God is skepper en Heer van die wêreld wat teenoor Hom staan, wat Hy regeer en in stand hou. Die ontwêreldliking van die mens bestaan daarin dat alhoewel hy uit die

3) Karl Barth, K.D. IV, 3/2 S. 880 . 
aarde aards is, hoewel hy in die wêreld is, is hy tog onderskeie deel van die wêreld. Volgens goddelike mandaat staan hy teenoor die wêreld met die opdrag om dit te onderwerp. Die evangelie maak God los van die wêreld, maar dis nie die belangrikste waarheid nie. Die belangrikste waarheid is dat as Skepper van die wêreld die wêreld nie los van God is nie. Die evangelie maak ook die mens los van die wêreld, maar dit is ook weer nie die vernaamste waarheid nie. Die vernaamste is dat die evangelie die mens in verbinding met die wêreld stel, met 'n taak en 'n roeping teenoor die wêreld.

Dat daar nog baie meer oor die skadusy van die sekularisasie as oor die lig gesê kan word, hoef nie verdedig te word nie. Ek volstaan deur enkele sake te noem wat vir ons tema belangrik is: Die sekularisasie en die daarmee gepaardgaande tegnologiese en wetenskaplike ontwikkeling op 'n menigte gebiede soos kommunikasie, ekonomie, handel, gesondheid, het miskien meer as ooit die wêreid in sy aardse gestalte onder die aandag van die kerk gebring. Dit het die teenstellings tussen ryk en arm, siek en gesond, honger en versadig meer as ooit in sy skerpte onder die aandag van al wat leef laat leef.

Die verowering van die hemelruim en die daarstelling van alle lewevernietigende wapens het van ons wêreld 'n nietige planeetjie gemaak waarop so veel miljoen mense as't ware vasgedruk sit onder die dreigende gevaar van selfuitwissing. As gevolg hiervan het die vraag na die toekoms en die voortbestaan van die wêreld ' $n$ baie brandende geword.

Hoe dat uiterlike wêreldlike omstandighede die teologiese diskussie en die lewe van die kerk kan bepaal, word baie duidelik as ons ' $n$ voorbeeld neem van cle betekenis van so ' $n$ uiters wêreldse aangeleentheid soos statistiek.") Ons het die afgelope jare baie gehoor van bevolkingsontploffing. Die grootste ontploffing vind plaas in die sg. ontwikkelende lande wat by uitstek die sendinggebiede van die kerk is. As gevolg van die ontploffings word die christendom ' $n$ al kleiner getal in ' $n$ sterker groeiende heidendom. Suiwer op getalle geoordeel, is die christendom aan die agteruitgaan in die wêreld. Daar word dan ook al gepraat van die feit dat die kerk bereid sal moet wees om in permanente diaspora in die wêreld te verkeer. Hierdie feitelike toestand in die wêreld, bloot op statistiese vlak, vind weerklank in die sendingteologiese diskussies. Terwyl die christendom numeries al meer invloed in die wêreld verloor, kom ' $n$ baie ou sendingsdoelstelling in die gedrang, $n l$. die numeriese uitbreiding van die kerk. Die reaksie in die sendingsdiskussie is dat dit in die sending nie om getalle gaan nie, dat die kerk nie na sukses moet kyk nie, maar gehoorsaam sy taak moet verrig en die sukses aan God oorlaat. Andere wys weer daarop dat dit in die Bybel

4) Hans-Werner Gensichen, Glaube für die Welt, Gütersloh, 1971, S. 32. 
(Handelinge) tog ook om numeriese groei van die kerk moet gaan. Tot so 'n mate word daar kant gekies teen die gedagte van kerkvorming en -uitbreiding dat iemand soos Hoekendyk pleit dat elke sweem van bekering uit die doelstellings van die kerk moet verdwyn. Die kerk moet hom heeltemal verander: die kerk wat die wêreld wil omvat, moet die kerk vir almal word. Die kerk moet verander tot broederlik-in-die-wêreld-wees, hy moet alleen dialoog met die wêreld voer en geensins bekeer nie.

3(iii). Na hierdie ekskurs om aan te toon hoe dat veranderinge in die wêreld die kerklike spreke en handeling kan beïnloed, wil ons weer terugkeer na die uitgangspunt by die bespreking van die diepere probleme rondom die stem van die kerk in die wêreld. As mees betekenisvolle faktor in hierdie verband het ons die sekularisasie van die wêreld genoem Sekere ontwikkelinge in die moderne teologiese denke, veral op die gebied van die sending, maak dit moontlik om die verdiskontering van die sekularisasieteologie te evalueer. Arend van Leeuwen het dit in sy Christianity in world history sterk laat deurskemer, en dit word blykbaar tans algemeen aanvaar, dat die westerse kultuur soos wat ons hom vandag in sy gesekulariseerde gestalte van wetenskap en tegniek vind, beskou en verstaan moet word as ' $n$ anonieme christelike suurdeeg, as christendom incognito, wat besig is om die wêreld te deurtrek en sy heidense struktuur te vernietig. Met die triomftog van die gesekulariseerde westerse beskawing is ons op pad na die een toekomstige wêreld wat 'n christelike struktuur bevat waardeur nie net alle bestaande religieuse verskille betekenisloos gemaak word nie, maar wat die sending van die kerk in die wêreld reduseer en verskraal tot ' $n$ deelname aan 'n proses wat volgens sy eie immanente wette verloop en waarby aan die kerk hoogstens ' $n$ taak van interprestasie van hierdie proses toevertrou word. Die wêreldveranderende krag wat vroeër alleen van die evangelieverkondiging en die geloofsgetuienis van die gemeente verwag is, is nou in die nuwe gehominiseerde wêreld (gesekulariseerde wêreld) reeds aanwesig as 'n immanente dinamiek wat hom as 'n revolusionêre moontlikheid onbelemmerd kan ontwikkel. ${ }^{5}$ ) Dit gaan in die diens van die evangelie nie meer om 'n konfrontasie tussen kerk en wêreld nie, want eintlik bestaan daar nie meer 'n teenstelling nie. Eintlik gaan dit nie meer om evangeliedens nie, maar om spekulasie oor die feitelike samehang van kerk en wêreld. Volgens Friedrich Mildenberger in sy .,Theologie für die Zeit" gaan dit vir die nuwerer teologie eintlik om ' $n$ religieuse interpretasie van die werklikheid. Die religieusiteit van wêreld en mens bestaan daarin dat hulle aangelê is op God. Die mens het wesenlik 'n aanleg vir die geloof, en Bybel, verkondiging, openbaring help hom slegs om homself te verwerklik. (BI. 136-138.) Een ding word baie duidelik uit die sekularisasie-

5) Gensichen, a.w., S. 28. 
teologie, en dit is dat die verkondiging van die evangelie hoe langer hoe meer as oorbodig beskou word. Die sekulêre revolusie is van so 'n aard en intensiteit dat hy die sending van die kerk reeds verbygesteek het, terwyl die moderne geskiedenis van vooruitgang op kultuur, wetenskaplike en tegniese gebied gesien moet word as ' $n$ moment in die proses van die selfverwerklikende openbaring van God en van sy Ryk.

in lyn met hierdie gedagte lê die opvatting van Karel Rahner, dat die hele mensheid kragtens die versoening in Christus aktueel verlos is. Die bediening van cie versoening waarvan Paulus praat, d.w.s. die verkondiging van die versoening, kom hier in die gedrang en is skynbaar oorbodig. Dis nie meer nodig om mense deur geloof en bekering in die kerk te versamel nie.

Vanuit sekularistiese vooron derstellings word soms 'n christendom sonder Christus geproklameer. Volgens hierdie beskouing kan die christendom alleen gered word as hy so gou moontlik die christusmitologie ontmitologiseer. Die liefde van God wat die mens nodig het vir sy bestaan, so word beweer, is altyd en oral teenwoordig, sonder besondere draers van die heil soos Jesus Christus. ${ }^{6}$ ) Christus word oorbodig.

3(iv). Ek wil u nie vermoei en verveel met meer afwykende voorbeelde van denke oor die verhouding tussen kerk en wêreld vandag nie. Dit kan alleen gekonstateer word dat die diskussie rondom die probleem kerk en wêreld, kerk en mensheid vandag in 'n groot impasse beland het. Aan die een kant het ' $n$ mens 'n radikale teenkanting teen elke gedagte van kerkplanting soos wat Voetius van weleer die doel van die sending geformuleer het. Eintlik word die hele gedagte van die kerk verwerp. Dit gaan nie om kerkwording van die wêreld nie, maar om wêreldwording van die kerk. Hierdie woordvoerders verbaas hulle daaroor dat nie ingesien kan word nie dat God vandag buite die kerk om in die wêreld besig is om te handel en dat daar in die sending nie meer plek is vir die versameling van gemeentes nie. Die vraag is, in die lig van so 'n beskouing, of daar moontlikheid oor is vir die kerk om die heilsgebeurtenisse van God in Christus verder aan te kondig. en of hy hom maar moet aanpas by die proses van heilsontwikkeling in die wêreldgeskiedenis. Eintlik bly daar vir die kerk alleen die taak oor om ' $n$ bydrae te lewer tot die daarstelling van ' $n$ medemenslike gemeenskap en word dit ' $n$ vraag of daar nog enige sin in is om kerke in Afrika, Asië en Amerika te vorm. As ek die dieperliggende probleem van ons tema moet formuleer, sou ek dit so wou stel: die oorheersende opvatting vandag is dat dit glad nie meer gaan om die stem van die kerk in die wêreld nie, maar om die daad van die kerk in die wêreld. Dit gaan nie meer primêr om prediking van die evangelie nie, maar om die christelike handeling.

6) Gensichen, a.w., S. 31. 


\section{DIE WESE VAN DIE PROBLEEM}

4(i). Daarmee het ons by die grondlaag van die problematiek van ons onderwerp gekom, en moet ons probeer aantoon waarom dit wesenlik gaan. Hoe het dit daartoe gekom dat die stem van die kerk, die evangelieverkondiging, moet plek maak vir menslike aktiwisme? Behalwe uiterlike wêreldveranderinge, soos aangetoon rondom die woord sekularisasie, was daar ook innerlike kerklikteologiese veranderinge op die spel. $\mathrm{Na}$ die eerste wêreldoorlog beleef ons die opkoms van die sogenaamde apostolaatsteologie. Hierdie teologie was 'n reaksie teen en was bedoel as 'n poging om die kerk te verlos uit sy verstarde introversie. Die algemene gevoel was dat die kerklike struktuur rondom die plaaslike gemeente met sy binnekerklike lewe van geloof en belydenis in die gereelde erediens, buitentyds geraak het dat die kerk te veel na binne gekeerd lewe, hom te veel verlustig in die heerlike genot van die evangelie binne die vier mure van die kerk, te behep is met die gedagte van organisasie, stabilisasie en konservasie, terwyl hy almeer verval tot stagnasie en met lede oë aanskou hoe dat al meer van sy eie lidmate vervreemd raak van die kerk en die kerk homself skynbaar weinig bekommer oor die wêreld buite sy vier mure. Die apostolaatsteologie wou die kerk 'n ekstroverte kerk maak, 'n kerk wie se binneste na buite gekeer moes word, 'n kerk wat bewus moet wees van sy apostolêre taak, en 'n man soos Hoekendyk het dit dan ook as onbetwisbare feit byna fanaties gestel dat die kerk alleen in sy funksie as missionerende kerk werklik kerk is. Hoekendyk e.a. het die groot teenstanders van die sogenaamde kerksentriese sending geword en het teenoor die begrip kerk die begrip koninkryk gestel. 'n Kerk wat die wêreld en die koninkryk uit sy gesigsveld verloor, is nie meer kerk nie.

4(ii). Die sentraal stel van die begrip koninkryk, staan in noue verband met ' $n$ ander teologiese ontwikkeling wat ook aan die begin van die twintigste eeu gestel moet word, toe kerk en teologie werklik erns begin maak het met die betekenis van die eskatologie. Die verdiskontering van die Bybelse eskatologie in die sendingsdenke het radikale veranderinge meegebring veral wat die doelstellings van die sending betref. Met die nadenke oor die betekenis van die eskatologie het die toekoms van kerk en wêreld besondere aandag geniet. Woorde en begrippe soos belofte, hoop, toekoms, het opnuut begin lewe in die teologie, en kerk en wêreld is al meer en meer gesien in hulle gerigtheid op die eskatologiese heil. Soos meermale in die geskiedenis van die kerk, het ook nou weer geblyk dat saam met een locus van die teologie, die hele res in beweging kom. Behalwe die eskatologie het veral ook die leer oor die versoening besondere belangstelling begin geniet. Uitgaande van veral 2 Kor. 5:17 (Daarom, as iemand in Christus is, is hy 'n nuwe skepsel; die ou dinge 
het verbygegaan, kyk dit het alles nuut geword) het die gedagte aan die verwesenliking, die realisering van die nuwe mensheid, die realisering van die koninkryk van God waardeur daar meer ruimte vir geregtigheid in hierdie wêreld geskep moes word, al sterker na vore gekom. Gedryf deur die ywer vir die realisering van die koninkryk van God, het daar in die jongste tyd die nuwe teologiese denkrigtings ontstaan: die teologie van die hoop, die teologie van die struktuurkritiek, die politieke teologie, die teologie van die revolusie. In al hierdie gedagtegange merk 'n mens 'n ontevredenheid met die bestaande orde en 'n koorsagtige ywer om deur menslike handeling op politieke en maatskaplike vlak die samelewingstruktuur te verander om op hierdie wyse die hoop op die eskatologiese heil te laat oorgaan in aanskouing. Volgens hulle is die tyd verby om oor die toekoms te praat, die tyd het aangebreek dat daar nou iets gedoen moet word om die toekoms wat ons beloof is, kragdadig te verwerklik.

4(iii). Wat werklik hier in die geding is, het van Niftrik m.i. voortreflik onder woorde gebring: (Kerk en Teologie, 23e. jg., No. 1, Jan. 1972. p. 20-33).

4(iii) (a). Dit gaan hier om 'n keuse tussen lewe uit die heil wat eens en vir altyd en vir almal beslissend plaasgevind het en wat aan die einde van die wêreld aan ons openbaar sal word, en waarmee ons met 'n gevoel van geborgenheid die toekoms tegemoet kan gaan met hoop en blydskap, óf 'n lewe van die heil wat nog verwerklik moet word aan die einde van die tyd wat grotendeels ons verantwoordelikheid is. Die moontlikheid van die toekoms het God in Christus geskenk, maar die verwerkliking daarvan is ons verantwoordelikheid. Wat in Christus reeds plaasgevind het, sê van Niftrik, is volgens hierdie beskouing slegs 'n beginnetjie wat deur menslike handeling voltooi moet word.

f(iii) (b). Dit gaan hier om 'n afwyking van die reformatoriese beskouing oor die verband van regverdiging en heiliging. Wel kan die twee nie geskei word nie, maar hulle moet onderskei word. Om die heiliging te eensydig te beklemtoon, word te veel waarde toegeken aan die menslike handeling, sowel in die algemeen as op die maatskaplike en politieke gebied. Nooit mag vergeet word dat die gelowige maar net ' $n$ klein begin van die gehoorsaamheid het en dat daar nie te veel op sy dade van dankbaarheid gebou moet word nie. Ook hierdie dade staan nooit los van die regverdiging van die goddeloses nie. Die eensydige oorbeklemtoning van die menslike dade impliseer die gedagte van koöperasie met God en is 'n vergryp teen die sola gratia.

4(iii) (c). Die teologie van die revolusie en die struktuur-kritiek is in stryd met die sondeleer van die Bybel. Volgens hierdie teologie 
sal menslike sondige vergrype verdwyn as die strukture van die samelewing maar verander word. Die Bybel leer egter nie dat die mens goed is en die samelewing sleg nie, maar dat die kwaad in die hart, in die wese van die mens setel. As die hart nie verander, vernuwe word deur die vergewende genade nie, sal geen struktuurverandering in staat en maatskappy die mens verander nie.

Die kerk het wel iets om te doen: God het hom geroep om te getuig van die groot dade van Sy heil, om deur diens van die Woord die heil te openbaar. Daar is wel 'n revolusie moontlik en nodig, maar nie die uiterlike revolusie van menslike aktiwiteite nie, maar die innerlike revolusie, of liewer die revolusie van binne uit, soos die suurdeeg die hele meel deursuur.

\section{KONKLUSIE}

5(i). Dat die kerk 'n stem het, is sy kosbaarste besit en om te spreek in die wêreld is sy primêre en hoogste roeping. Die kerk sal vandag nougeset moet toesien dat hierdie besit, reg en vryheid hom nie ontneem word nie. Hy sal moet waak teen die versoeking om i.p.v. kerk van die Woord, kerk van die daad te word. Die kerk het nog altyd meer bereik deur wat hy gesê het as deur wat hy gedoen het. Die krag van die kerk is geleë in die Woord wat hy verkondig en nie in die daad wat hy doen nie. Daar is vandag ' $n$ geweldige degradering van die verbale verkondiging aan die gang, terwyl die klem gelê word op die verkondiging deur die daad. Op die morele vlak is dit miskien 'n bedenklike saak dat mense gewoonlik mooier praat as wat hulle handel, en miskien geld dit in die algemeen van alle mense dat wat hulle sê altyd mooier is en mooier klink as wat hulle doen. Wat die kerk egter betref, is dit geen bedenklike saak nie. Die kerk se woorde sal altyd kragtens sy wese mooier en beter wees as sy dade. Sy woord is immers ' $n$ woord van heil omdat dit draer is van die heilsdaad van God in Jesus Christus. Die evangelie wat verkondig word, is ' $\mathrm{k}$ krag van God tot saligheid. Sy dade (die van die kerk) is immers geen heilsdade nie, maar dankbaarheidsdade, gehoorsaamheidsdade, en die kerk weet maar al te goed dat hy nog maar net ' $n$ klein begin van die gehoorsaamheid geleer het. Daar is geen heil vir die wêreld in wat hy doen nie, behalwe in die een daad, die daad van verkondiging van die groot dade van God vir die wêreld. (By Paulus gaan dit om die geloof alleen, die selfstandige heilsbetekenis van die wetswerke word verwerp. By Jacobus gaan dit om die noodsaaklike verband tussen geloof en werke, dus om geloof as eksistensiële saak. Dit gaan om teenstelling tussen heilswerke en geloofswerke).

5 (ii). Die stem van die kerk sal alleen dan in die wêreld ernstig geneem word as hy gedra word deur die kwaliteit van sy inhoud. M.a.w. die kerk kan alleen effektief praat as dit Bybels verantwoord is. Daar lê die grootste probleem wat betref die stem 
van die kerk in die wêreld. Die nood van die kerk deur al die eeue sou 'n mens miskien kon aandui met die omspanning van twee woorde in ons tema: die stem van die wêreld in die kerk. Hoe dikwels was dit nie wêreldwysheid, heidense filosofie, verchristelike ideologie wat in die stem van die kerk geklink het nie. Dan hoor die wêreld nie die stem van die kerk nie, maar in die stem van die kerk homself. Vandag is die tendens nie om die onveranderlike ewige evangelie anders in ' $n$ veranderde wêreld te spreek nie, maar uitgaande van die veranderde wêreld, ' $n$ ander evangelie aan te bied. Dit is nodig dat die kerk in die taal van sy tyd sal spreek. Dit is nodig dat die kerk die veranderde wêreld tot wie hy spreek goed sal ken. Die objek en wyse van spreke bepaal egter nie die inhoud van die spreke nie, maar die inhoud en die objek bepaal die wyse.

5(iii). Die stem van die kerk in die wêreld het ons vantevore reeds aangedui as die stem van ons kerk in ons wêreld. Ons kerk se stem is nie die enigste nie. Daar is die stem van ander kerke naas ons. Aan sommige van hulle staan ons nader as aan ander. Baie van hulle is groter as ons. Dit maak egter nie so veel saak nie. Groot manne het soms ' $n$ ou piepstemmetjie en kleintjies verbaas mens soms met die volume van hulle stem. Van belang is dat daar inhoud sal wees. As ons hoorbaar wil wees en wil bly in die wêreld, sal ons almal nog baie harder moet studeer. 